\title{
Recruitment of FOR20 and OFD1 onto pericentriolar satellites and centrosomes depends on the formation of a ternary complex with KIAA0753
}

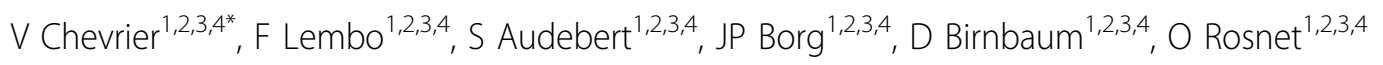

From Cilia 2014 - Second International Conference

Paris, France. 18-21 November 2014

Stable microtubules organized on the basis of a ninefold rotational symmetry constitute the structural basis of centrioles and basal bodies. A number of proteins associate with these structures to drive the process of centrosomes and cilia formation and to participate in their function. Pericentriolar satellites are small roundshaped particles closely associated with microtubules with PCM1 as a major component. To date they have been described only in vertebrates where they participate in the recruitment of proteins to the centrosomes and cilia. We identified the poorly characterized KIAA0753 protein as a direct interactor of FOR20, a pericentriolar satellite protein required for basal body integrity and ciliogenesis. This binary association allows the recruitment of OFD1, a centriole distal-end protein and regulator of centriole length, to form a ternary complex associated with pericentriolar satellites. Inhibiting expression of KIAA0753 by small inhibitory RNA limits the recruitment of FOR20 and OFD1 onto pericentriolar satellites and centrosomes, and decreases cilia length in serum-starved RPE1 cells. We also show that KIAA0753 has a microtubule-stabilizing activity. We propose that pericentriolar satellite and associated proteins such as PCM1 and KIAA0753 appeared in the course of early metazoan evolution to regulate ancestral eukaryotic centriole/basal body proteins such as FOR20 and OFD1.

\section{Authors' details}

${ }^{1}$ Aix-Marseille University, Marseille, France. ${ }^{2}$ Cancer Research Center of Marseille, Marseille, France. ${ }^{3}$ INSERM, Marseille, France. ${ }^{4}$ Institut PaoliCalmettes, Marseille, France.

${ }^{1}$ Aix-Marseille University, Marseille, France

Full list of author information is available at the end of the article
Published: 13 July 2015

doi:10.1186/2046-2530-4-S1-P69

Cite this article as: Chevrier et al:: Recruitment of FOR20 and OFD1 onto pericentriolar satellites and centrosomes depends on the formation of a ternary complex with KIAA0753. Cilia 2015 4(Suppl 1):P69.
Submit your next manuscript to BioMed Central and take full advantage of:

- Convenient online submission

- Thorough peer review

- No space constraints or color figure charges

- Immediate publication on acceptance

- Inclusion in PubMed, CAS, Scopus and Google Scholar

- Research which is freely available for redistribution
C Biomed Central 